\title{
Invasion of non-indigenous suckermouth armoured catfish of the genus Pterygoplichthys (Loricariidae) in the East Kolkata Wetlands: Stakeholders' perception
}

\author{
AJMAL HUSSAN, J. K. SUNDARAY², R. N. MANDAL, FARHANA HOQUE, ARABINDA \\ DAS, P. P. CHAKRABARTI AND S. ADHIKARI \\ Regional Research Centre of ICAR-Central Institute of Freshwater Aquaculture, Rahara - 700 118, West Bengal, India \\ *ICAR-Central Institute of Freshwater Aquaculture, Kausalyaganga, Bhubaneswar - 751 002, Odisha, India \\ e-mail: jsundaray@gmail.com
}

\section{ABSTRACT}

Rapid spread and population increase of suckermouth armoured catfishes belonging to the genus Pterygoplichthys (Loricariidae) in the East Kolkata Wetlands (EKW) in recent times is of increasing concern, because of the notable possibility that these non-native catfishes are adversely affecting fish germplasm and commercial fishery of this unique ecosystem. To study the present status of these loricariids and the invasion and impact dynamics in EKW ecosystems, field survey was conducted over a water spread area of 670 ha, comprising 120 fishermen $\left(\mathrm{N}_{2}=120\right)$ of 30 farms $\left(\mathrm{N}_{1}=30\right)$, between February and October, 2017 through a pre-tested, open-ended structured schedule. A total of 943 specimens of Pterygoplichthys spp. were collected and analysed for abundance, length-weight parameters, gonado-somatic index and relative fecundity. Pterygoplichthys spp. occurred at $29(97 \%)$ of 30 surveyed farms and approximately $70 \%$ of the farm owners perceived that these fishes posed moderate to serious economic impact. Fish production cutback, small indigenous fish (particularly, Puntius spp.) depredation and bottom structure alteration are among the major negatives perceived; a positive note in terms of soil-bound nutrient release was reported by a few fishermen (1\%). Channel through which sewage water intake occurred by gravitation has been perceived to be the main route of entry (77\%), with significantly higher abundance around the periphery of the pond. Almost $80 \%$ respondents perceived an increased occurrence of these fishes over the last four years, with seasonal pattern of abundance. Culling of suckermouth after harvest was the most common method adopted to reduce population. Multi-layer screening in the inlet of sewage water into the ponds is perceived as most sought solution for control. Average direct and indirect financial losses due to Pterygoplichthys spp. in EKW was calculated as ₹ 0.092 lakh ha-1 $\mathrm{yr}^{-1}$, which points towards mounting pressure of loricariids in already dwindling economics and biodiversity of EKW.

Keywords: Biodiversity, East Kolkata Wetlands, Invasion, Pterygoplichthys, Sewage

\section{Introduction}

Invasions by non-native species have been recognised as one of the major threats to biodiversity (Garcia-Berthou, 2007) and are known to cause significant ecological and economic damage as evidenced from the classic publication of Elton (Elton, 1958). Human domination of the Earth's ecosystems and economic globalisation have accelerated the rate of introduction of non-native species (Kolar and Lodge, 2001; 2002; Rahel, 2002) leading to extinction of many native or endemic species worldwide (UN, 1992; Clavero and Garcia-Berthou, 2005; 2006). Aquaculture and aquaria are mainly responsible for introduction of ornamental and economically important fish species to newer environments (Chavez et al., 2006). About one third of the world's worst aquatic invasive species are ornamental fishes (Padilla and Williams, 2004) and the ever increasing trade of ornamental aquarium fishes is one of the most important pathways for aquatic bio-invasion (Rixon et al., 2005; Raghavan et al., 2013), which is one of the major causes of biodiversity loss, particularly in freshwater systems (Sato et al., 2010). Taking advantage of limited number of legislations on fisheries, particularly on ornamental fish trade, many alien fish species have been covertly brought into India by hobbyists and aquaindustrialists for aesthetic or economic reasons for the past two decades (Lakra et al., 2008; Singh and Lakra, 2011). Escape or releases of these non-indigenous species into natural water bodies has dramatically altered the native fish diversity of many natural water bodies of the country and contributed to the decline and extinction of numerous species (Peh, 2010; Singh and Lakra, 2011; Singh et al., 2013).

Fishes of the family Loricariidae, represent a large family of the order Siluriformes including more than 700 
species (Ferraris, 2007) that inhabit freshwater habitats of tropical America, mainly occurring in the lower, middle and upper Amazon River basin of Brazil and Peru (Weber, 2003; Page and Robins, 2006) and distributed between $35^{\circ} \mathrm{S}$ to $12^{\circ} \mathrm{N}$ latitude (Berra, 2001). Loricarids have been identified as great threat to global freshwater fish diversity (Orfinger and Goodding, 2018). Due to characteristic attractive appearance, these fishes have high popularity for the aquaria and species like Pterygoplichthys pardalis and Pterygoplichthys multiradiatus have been regularly bred and exported from Singapore (Muralidharan et al., 2015). Although there is wide variation, loricariids are characterised by a depressed body covered by large bony plates, a unique pair of maxillary barbels and a ventral suctorial mouth (Covain and Fisch-Muller, 2007). Among the loricariids, many species of the genus Pterygoplichthys (subfamily Hypostominae) have established populations in many parts of the world. Loricariids begun to appear outside of their native range in the second half of the $20^{\text {th }}$ century, first in Central America (Wakida-Kusunoki et al., 2007) and later, they were introduced/invaded into inland water bodies of many countries across the world, viz., Hawaii (Eldredge, 2000), Philippines (Hubilla et al., 2007), Japan (Nakabo, 2002), Taiwan (Liang et al., 2005; Wu et al., 2011), Vietnam (Levin et al., 2008; Zworykin and Budaev, 2013), Indonesia (Herder et al., 2012), Malaysian Peninsula, Java, Sumatra and Singapore (Page and Robins, 2006; Samat et al., 2008), Sri Lanka (Sumanasinghe and Amarasinghe, 2013), Israel (Golani and Snovsky, 2013), Turkey (Ozdilek, 2007), Bangladesh (Hossain et al., 2008), Mexico (Armando et al., 2007), Eurasia (Piazzini et al., 2010; Chaichana et al., 2011) and India (Knight, 2010; Sinha et al., 2010; Bijukumar et al., 2015). Intentional release of these fishes by the aquarium keepers, suppliers and breeders of aquarium fishes into natural water bodies and easy adaptation, breeding and high survival rate are probably the major cause of their worldwide invasion (Liang et al., 2005; Page and Robins, 2006; Bijukumar et al., 2015).

In India, suckermouth armoured catfishes have been reported from Andhra Pradesh, Bihar, Kerala, Tamil Nadu, Telangana, Uttar Pradesh and parts of West Bengal (Knight, 2010; Sinha et al., 2010; Singh, 2014; Bijukumar et al., 2015; Muralidharan et al., 2015; Mogalekar et al., 2017; Rama Rao and Sunchu, 2017; Hussan et al., 2018). Invasion of these fishes to the aquatic habitats have serious ecological and economic consequences (Nico et al., 2012), as a result of food chain disruption by overgrasing of benthic algae (Liang et al., 2005; Chavez et al., 2006), competition with native fishes (Nico and Martin, 2001); substrate modification (Hoover et al., 2004) and damage due to burrowing habit (Bunkley-Williams et al., 1994). In East Kolkata Wetlands (EKW), Pterygoplichthys sp. was first reported from Gomokpota Beel in 2009 (ICAR, 2009). Since then these catfishes have invaded widely and proliferated profusely in the water bodies of EKW (Hussan, 2016; Hussan et al., 2016), which may be having negative effects on the native fishes as well as commercial fisheries of EKW. EKW, one of the Ramsar sites in West Bengal (Ramsar, 2017), located on the eastern fringes of the Kolkata City is the world's largest wastewater ecosystem created to sustain successive resource recovery systems in the form of vegetable farms, fish ponds and paddy fields. An estimated $30-50 \%$ of the sewage generated by the Kolkata City is treated and reused by the fishponds of the EKW (Edwards, 2008). Wastewater is introduced into the fishponds in batches or continuously, mainly taking advantage of gravity. Though effective area under fish farms in EKW has reduced from 7,300 ha in 1945 to around 2,481 ha in recent time (EKW, 2010), its 264 functioning aquaculture ponds, locally called bheries, currently produces over $15,000 \mathrm{t}$ of fish per annum (EKW, 2010). Conversion of wetlands for settlements and agriculture, fragmentation of wetlands into relatively smaller patches, reduced capacity of the canals due to siltation, release of industrial waste water containing pesticides and heavy metals and injudicious introduction/ invasion of exotic fishes are posing threat to this unique ecosystem upon which livelihood of a large, economically underprivileged population of around 27,000 families depends (SAC, 2010).

The present study was conducted to investigate the abundance and status of invasion of loricariids of the genus Pterygoplichthys in EKW and to assess their impact on biodiversity, commercial fisheries and aquaculture economics of this wetland system of international importance under the Ramsar Convention.

\section{Materials and methods}

\section{Data collection}

Field survey was conducted over a water spread area of 670 ha $\left(\mathrm{S}_{1}=670\right.$ ha) of East Kolkata Wetlands (EKW, $22^{\circ} 25^{\prime}-22^{\circ} 40^{\prime} \mathrm{N} ; 88^{\circ} 20^{\prime}-88^{\circ} 35^{\prime}$ E) (Fig. 1) between February and October 2017. During this period, 30 big farms of 10 to 50 ha $\left(\mathrm{N}_{1}=30\right)$ in EKW were surveyed and 120 fishermen $\left(\mathrm{N}_{2}=120\right)$ of these farms were interviewed. Fish collection was accomplished through drag netting of around 78 ha $\left(\mathrm{S}_{2}=78 \mathrm{ha}\right)$ of fish culture ponds of these farms at random points. Fishes were collected as bycatch in the commercial fish harvest from 3 sites of EKW: a) North-west site [Bidhanagar area (BID)], b) South site [Anandapur area (ANA)] and c) East site [Kolkata Leather Complex area (KLC)]. Specimens collected were identified based on the keys provided by Weber (1991, 1992), Armbruster (2001), Armbruster and Page (2006) 


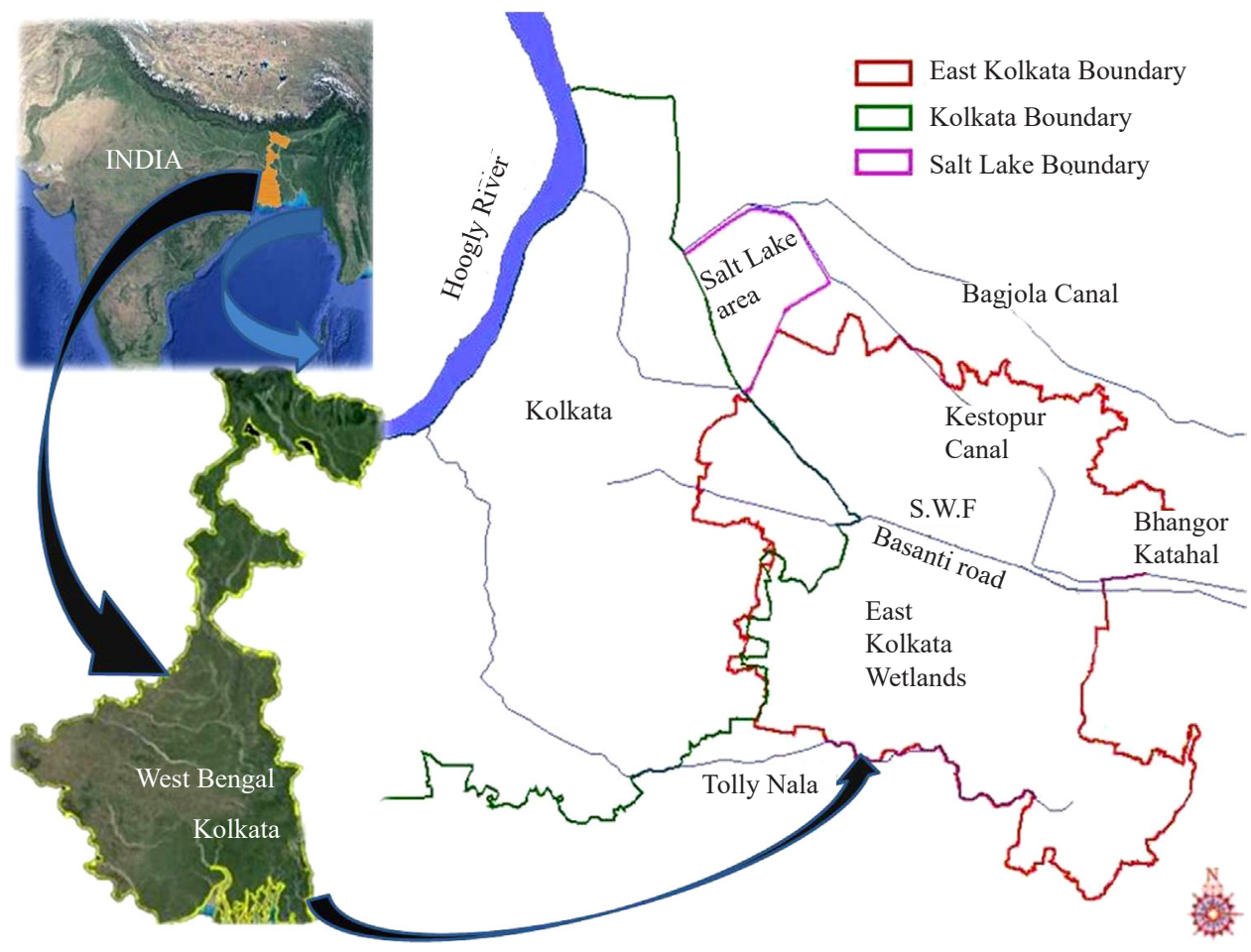

Fig. 1. The survey site: East Kolkata Wetlands, West Bengal

and Jumawan et al. (2011). Morphometric analysis was carried out following the methods of Armbruster (2003) and Armbruster and Page (2006). Measurements were taken with digital calliper to the nearest millimeter ( $\mathrm{mm})$ and weight to the nearest gram (g) using a digital balance.

To get quantitative data and to estimate magnitude of the impact of Pterygoplichthys spp. in pond fisheries of EKW, we conducted a face-to-face open ended questionnaire survey, as in-person interviews allow researchers to add clarifying questions and considered to be more effective than mailed questionnaires (Parkhurst et al., 1987; Skaren, 1990; Trindade, 1991; Graham et al., 2005). We involved the farm owner/farm manager and three long serving employees of each farm and interviewed them individually to affirm the results. Questions were asked mostly on the magnitude and trends of armoured catfishes presence in their ponds, whether any economic losses at their farms attributable to armoured catfishes and also about the impact they perceive to be causing by these catfishes. Although pond owners perception or observation of losses due to a factor not always reflect the actual economic concern (Freitas et al., 2007) and likely to be biased by owner's economic interest (Kloskowski, 2005), their perceptions of damage embed by factor concern may be critical to get idea about the magnitude of concern and for identifying means for minimising losses (West and Parkhurst, 2002). Information on damage control measures practiced by EKW farmers to control/eradicate Pterygoplichthys along with basic farm information like farm size, water supply source, species and age-classes of farmed fish, productivity, trends of harvesting of fishes including small indigenous fishes for the past 5 years were collected.

\section{Data analysis}

Descriptive statistics of frequency tables, simple percentage and averages were used for the generation of conclusion. Data were analysed thematically and computed as statistical tables and graphs. Overall perception percentage towards impact of Pterygoplichthys spp. was calculated by dividing the number of response against a particular perception by total number of respondents. The length-weight relationship was estimated using the equation, $\mathrm{W}=\mathrm{aL}^{\mathrm{b}}$ given by Le Cren (1951); where $\mathrm{L}$ is the body length and $\mathrm{W}$ is the body weight of fish. Phases within the reproductive cycle were identified based on Brown-Peterson et al. (2011). The gonado-somatic index (GSI) was determined only for females at advanced stages of spawning $(\mathrm{n}=14)$ and calculated using the formula: GSI $=100 \times(\mathrm{Wg} / \mathrm{W})$ (Solomon and Ramnarine, 2007; Simon et al., 2009) where Wg is the weight of wet gonad (g) and $\mathrm{W}$ is total wet body weight without gonad (g). Absolute fecundity (AF) was determined as the product of 
gonad weight and oocyte density using the formula (Murua et al., 2003):

$$
\mathrm{F}=\frac{\sum_{\mathrm{i}} \frac{\mathrm{o}_{\mathrm{i}}}{\mathrm{W}_{\mathrm{i}}}}{\mathrm{n}} * \mathrm{~W}_{\text {ovary }}
$$

where, $\mathrm{O}_{\mathrm{i}}=$ Oocyte density (oocytes / g ovary), $\mathrm{W}_{\mathrm{i}}=$ weight of the subsample of the ovary, $\mathrm{W}_{\text {ovary }}=$ Weight of the entire ovary and $\mathrm{n}=$ No. of subsamples

Oocyte density (number of oocytes per gram of ovarian tissue) was determined by counting the number of oocytes from 3-5 subsample of ovarian tissue of known weight. Each subsample was weighed to the nearest $0.1 \mathrm{~g}$ and then dispersed manually to segregate and count all mature oocytes. Relative fecundity (RF) was calculated as $\mathrm{RF}=\mathrm{AF} / \mathrm{W}$, where $\mathrm{W}$ is the body weight of fish.

\section{Results}

In our study, we found large number of suckermouth armoured catfishes (Loricariidae) with a wide range of body sizes, which indicates that a self-maintaining population of armoured catfishes have invaded EKW. These catfishes particularly of the genus Pterygoplichthys are not only occasionally found in the sewage distributaries of EKW, but are quite abundant in almost all the ponds surveyed. A total of 943 specimens of Pterygoplichthys spp. (Fig. 2)

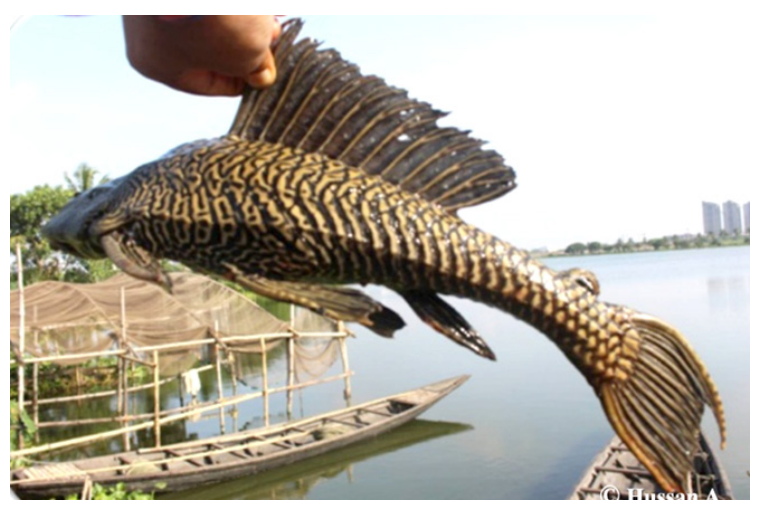

Fig. 2. Pterygoplichthys disjunctivus (Weber, 1991) were collected during the study, with abundance ranging from 3 to 22 nos. ha ${ }^{-1}$. Abundance was found significantly lower in east side of EKW, that is around KLC area, where supply of wastewater through canal is limited and ponds are of comparatively smaller size which get dried up more frequently. Fish collection through netting ( $10 \pm 5$ nos. $\mathrm{ha}^{-1}$ ) was found significantly lower in all sampling sites, than the perceived abundance of these fishes in EKW by the fishermen (15-150 nos. ha-1) (Table 1). Netting error, burrowing habit of these fishes, regular culling of these fishes caught during food fish harvest and/or hide-outs of these fishes below Eichhornia layer along the periphery of the ponds are probably the reason behind the low catch achieved through netting.

Morphological traits of the individuals collected were carefully evaluated and compared between fish caught in the EKW and several common Pterygoplichthys spp. reported in different scientific papers. Based on external traits and pattern of the colouration/spots in belly we found about $16 \%$ individuals have greater resemblance with $P$. disjunctivus (Fig. 3a-b) and all other (84\%) fishes have intermediate patterns (Fig. 3c-f), not fully resembling any Pterygoplichthys species description externally. $P$. pardalis which has spotted pattern with discrete black spots on the ventral side of the body (Armbruster and Page, 2006) was not recorded during the study; however, specimens with intermediate patterns were encountered which would most probably be hybrid between $P$. pardalis and $P$. disjunctivus.

Total length (TL) of the fishes collected was found in the range of 229 to $498 \mathrm{~mm}$ with weight (W) of 86 to $1200 \mathrm{~g}$. The largest specimen of $1200 \mathrm{~g}$ with intermediate belly pattern was collected in the month of June from Bantala area of ANA. Although these fishes get slimmer with increasing length, as indicated by ' $b$ ' value, which is less than ' 3 '; $\mathrm{r}^{2}$ value of 0.941 indicates a strong linear relationship between total length and total weight. No significant difference was found in ' $b$ ' value and ' $\mathrm{r}$ ', value among the localities (Table 2). Occurrence of ripe female, apparently at maturing or spawning phase with ovary occupying $>50 \%$ of body cavity, orange in colour

Table 1. Summary of the sampling in the ponds of East Kolkata Wetlands (EKW)

\begin{tabular}{llllll}
\hline Sampling site & $\begin{array}{l}\text { Survey area } \\
\left(\mathrm{S}_{1}\right)(\mathrm{ha})\end{array}$ & $\begin{array}{l}\text { Area netted } \\
\left(\mathrm{S}_{2}\right)(\mathrm{ha})\end{array}$ & $\begin{array}{l}\text { Pterygoplichthys } \\
\left.\text { collected (from } \mathrm{S}_{2}\right) \\
(\text { no. })\end{array}$ & $\begin{array}{l}\text { Abundance as per on-field } \\
\left.\text { netting }(\text { no. ha })^{-1}\right)^{*}\end{array}$ & $\begin{array}{l}\text { Abundance as per } \\
\text { stakeholders } \\
\left(\text { no. ha }^{-1}\right)^{*}\end{array}$ \\
\hline BID & 315 & 26 & 417 & $14.0 \pm 5.0^{\mathrm{a}}$ & $80.0 \pm 32.0^{\mathrm{a}}$ \\
ANA & 245 & 30 & 361 & $11.0 \pm 4.0^{\mathrm{a}}$ & $69.0 \pm 23.0^{\mathrm{a}}$ \\
KLC & 110 & 22 & 165 & $7.0 \pm 2.0^{\mathrm{b}}$ & $33.0 \pm 13.0^{\mathrm{b}}$ \\
Pooled & 670 & 78 & 943 & $10.0 \pm 5.0$ & $59.0 \pm 30.0$ \\
\hline
\end{tabular}

"Mean \pm SD. Sampling sites: Bidhanagar area (BID), Anandapur area (ANA), Kolkata Leather Complex area (KLC). Values in the same column having different superscript letters are significantly different $(\mathrm{p}<0.05)$ among sampling sites. Data in the last raw represent the overall results of EKW. 

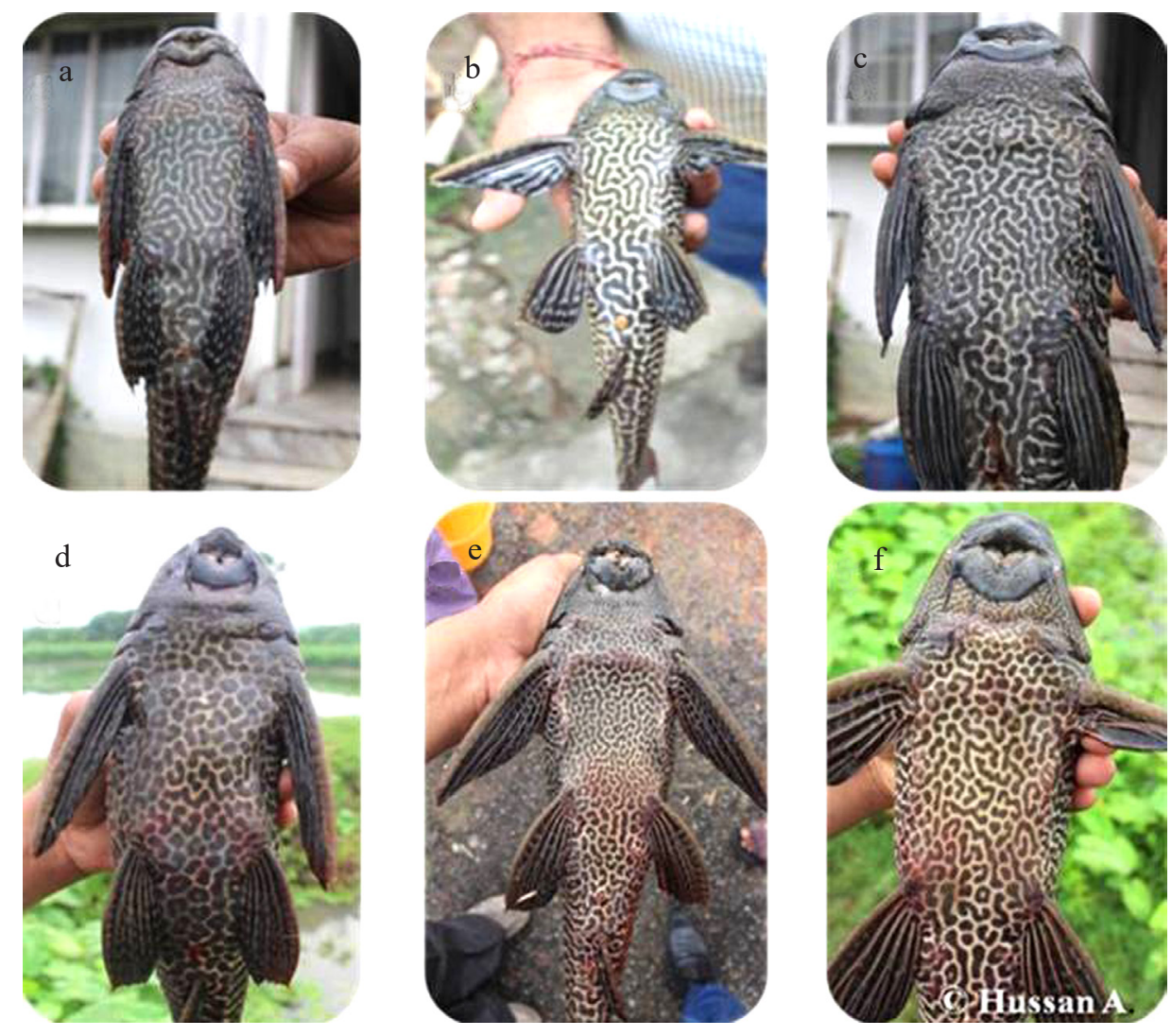

Fig. 3. Abdominal patterns of various specimens of Pterygoplichthys spp. a-b: P. disjunctivus species group; c-f: Inter-grades (Jumawan et al., 2011)

Table 2. The weight and total length (Mean $\pm \mathrm{SD}$ ), maximum and minimum values recorded, and the calculated values for the total length-weight relationship for Pterygoplichthys in three sites at EKW, West Bengal, India

\begin{tabular}{|c|c|c|c|c|c|c|c|c|c|c|}
\hline \multirow{2}{*}{ Locality/Site } & \multirow{2}{*}{$\mathrm{n}$} & \multicolumn{3}{|c|}{ Total length ${ }^{*}(\mathrm{~mm})$} & \multicolumn{3}{|c|}{ Total weight $^{*}(\mathrm{~g})$} & \multicolumn{3}{|c|}{$\mathrm{W}=\mathrm{aL}^{\mathrm{b}}$} \\
\hline & & Max & Min & Mean \pm SD & Max & Min & Mean \pm SD & a & $\mathrm{b}$ & $r^{2}$ \\
\hline BID & 417 & 498 & 232 & $315 \pm 69$ & 1200 & 91 & $289 \pm 231$ & 0.0179 & 2.81 & 0.938 \\
\hline ANA & 361 & 467 & 229 & $304 \pm 65$ & 830 & 86 & $227 \pm 170$ & 0.021 & 2.76 & 0.929 \\
\hline KLC & 165 & 412 & 267 & $318 \pm 54$ & 530 & 140 & $277 \pm 134$ & 0.0183 & 2.77 & 0.946 \\
\hline Pooled & 943 & 498 & 229 & $327 \pm 69$ & 1200 & 86 & $319 \pm 218$ & 0.0176 & 2.79 & 0.941 \\
\hline
\end{tabular}

with strong vascularisation, thin ovarian wall containing large oocytes from the month of August indicate onset of spawning of these fishes from the month of August/ September in EKW. The mean length and weight of 14 gravid females of armoured catfish found during

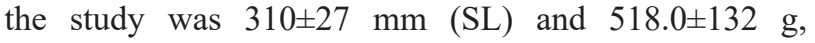
respectively. Ovary weights were recorded between 21.50 and $73.0 \mathrm{~g}$ and absolute fecundity estimates for the 14 females varied from 1606 to 4482 , with a mean estimate of 2705 eggs per ovary. The average GSI was calculated as $8.52 \pm 2.65$ with highest individual GSI value of 12.86 recorded in the month of October in a fish weighing $482 \mathrm{~g}$. The average relative fecundity of females was $6.31 \pm 1.97$ oocytes per g (Table 3 ).
Majority of the farms (80\%) we visited reported rapid increase in the quantity of armoured catfishes in their farms over last 3-4 years (Fig. 4) with notable impact on fish stock (Fig. 5) and annual income from fisheries (Fig. 6). Seventy percent (21/30) of the farms perceived a 'significant' (moderate or large) negative effect on their annual income by armoured catfishes, whereas, $16 \%$ perceived small to no effect. These catfishes were not reported to prey on cultured fishes, but nine out of thirty farms experienced significant stock depletion in their ponds due to proliferation of these catfishes. Proliferation of armoured catfish is also perceived as one of the reason behind the reduced abundance of small indigenous fishes, particularly Puntius spp. and Chanda spp. in EKW (Fig. 7). 
Table 3. Sex and maturity stages of Pterygoplichthys collected from EKW during July to October, 2017

\begin{tabular}{llllll}
\hline Sex & Maturity stage & Number of individuals & Standard length $(\mathrm{SL})(\mathrm{mm})$ & Weight $(\mathrm{g})$ & GSI \\
\hline Unsexed & Immature & 27 & $266 \pm 64$ & $323 \pm 84$ & - \\
Male & Developing & 16 & $306 \pm 52$ & $457 \pm 98$ & - \\
& Developing & 21 & $272 \pm 31$ & $383 \pm 121$ & - \\
Female & Mature/spawning stage & 14 & $310 \pm 27$ & $518 \pm 132$ & $8.52 \pm 2.65$
\end{tabular}

Data represented as mean \pm SE; GSI: Gonadosomatic index

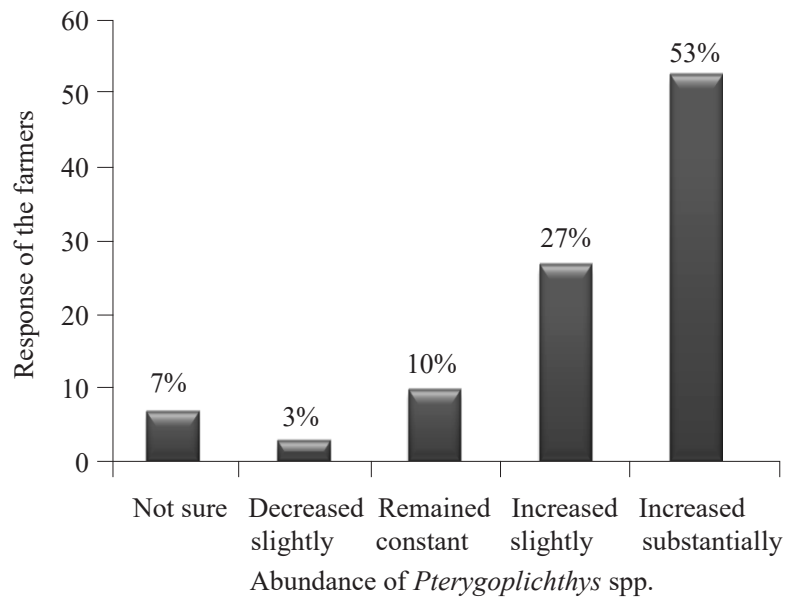

Fig. 4. Status of abundance of Pterygoplichthys spp. in EKW during 2014-17 $\left(\mathrm{n}=\mathrm{N}_{1}=30\right)$

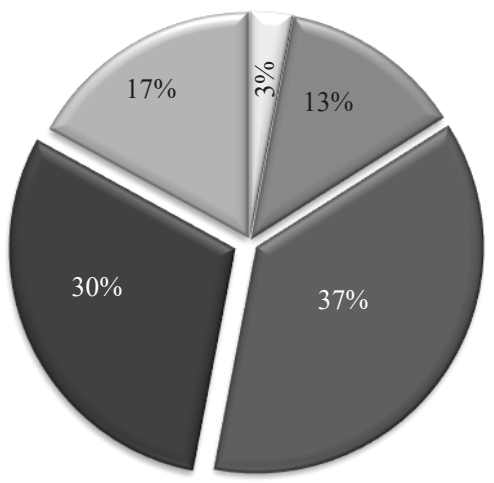

$\square$ Not present currently, $\square$ Present but have little impact on fish stock

- Present and have moderate impact on fish stock, 1 Present and have a serious impact on fish stock, $\square$ Present but do not have idea about impact on fish stock

Fig. 5. Impact of Pterygoplichthys spp. on fish stocks of EKW ponds $\left(\mathrm{n}=\mathrm{N}_{1}=30\right)$

Channel through which sewage water is taken to the pond using gravitational advantage has been perceived as the main route of entry (77\%) (Fig. 8), with significantly higher abundance around the periphery of the pond, particularly below the Eichhornia layer (Fig. 9). Abundance in terms of number was reported to be higher after monsoon (Fig. 10). Depredation of economically important food fishes and small indigenous fishes as well as damage

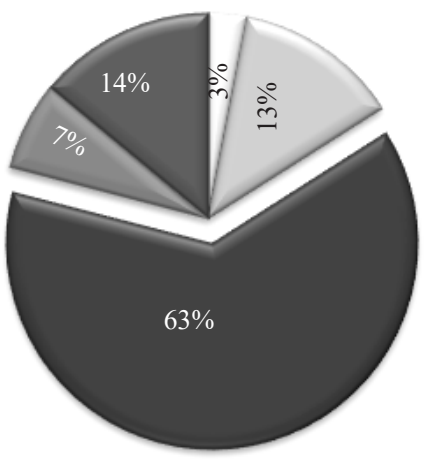

$\sqcup$ No effect, $\square$ Small effect, $\square$ Moderate effect

$\square$ Large effect, $\square$ Has effect but can not quantify

Fig. 6. Effect of Pterygoplichthys spp. on annual income from fisheries of EKW $\left(\mathrm{n}=\mathrm{N}_{1}=30\right)$

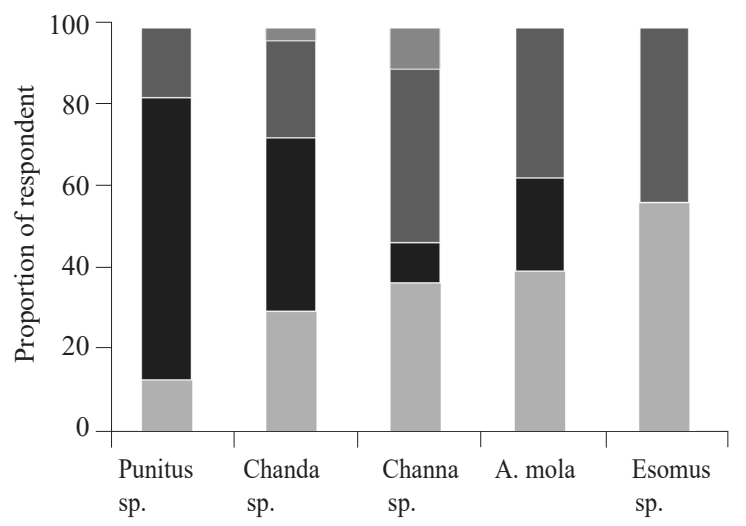

- Increasing, = Constant, $\square$ Decreasing, $\square$ No response

Fig. 7. Trends of indigenous small fishes catch at EKW between 2014 and $2017\left(\mathrm{n}=\mathrm{N}_{2}=120\right)$

to fishing gear were perceived to be the main negatives caused by Pterygoplichthys spp. Injuries/scratches in the bodies of economically important fishes due to presence of large quantity of armoured catfishes in the net during harvest were reported by 14 respondents of 6 farms. Excavation of burrows in pond dykes and pond bottoms along the periphery, by these fishes were also reported. Amid all negatives, a positive note in terms of soil-bound nutrient release by these fishes was reported by one fisherman (Table 4). As control measure, all the farms studied $(100 \%)$ employ culling of the fishes out 


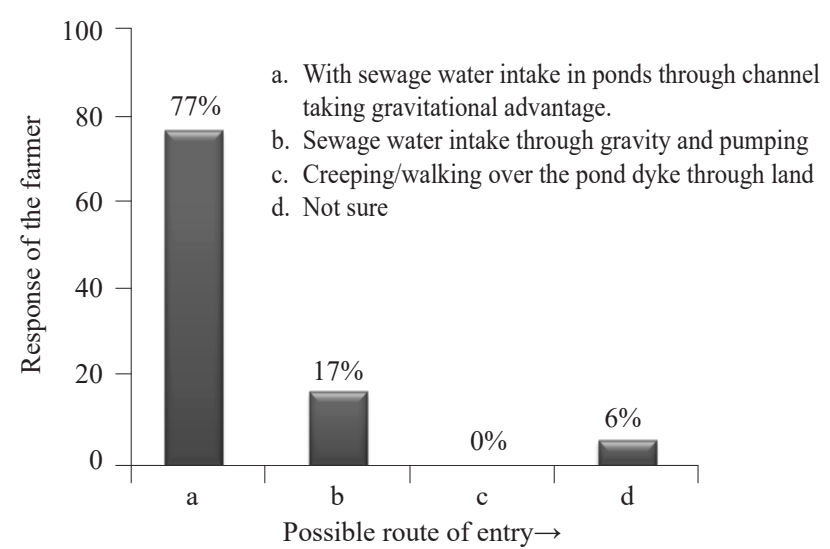

Fig. 8. Possible route of Pterygoplichthys spp. entry into the ponds of EKW $\left(\mathrm{n}=\mathrm{N}_{2}=120\right)$

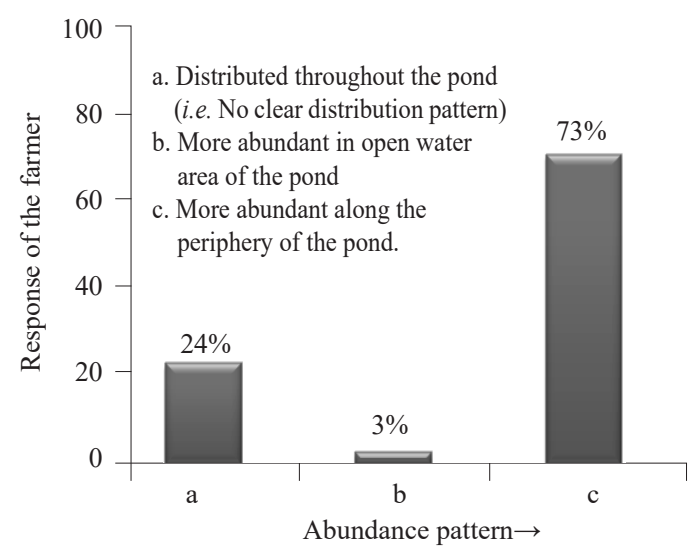

Fig. 9. Distribution pattern of Pterygoplichthys spp. in ponds of $\operatorname{EKW}\left(\mathrm{n}=\mathrm{N}_{2}=120\right)$

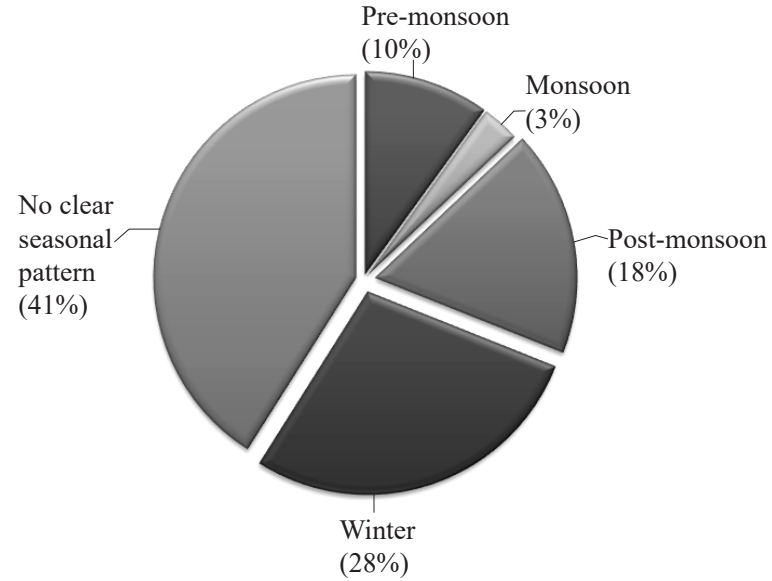

Fig. 10. Seasonal abundance pattern of Pterygoplichthys spp. in $\operatorname{EKW}\left(\mathrm{n}=\mathrm{N}_{2}=120\right)$

of the pond. Three farms also reported to pay additional amount to the fishermen in order to motivate them to catch Pterygoplichthys spp. as many as possible (Table 5). Multi-layer screening in the inlet of sewage water into pond and culling after repeated netting/drying has been perceived as the most sought solution for control (Table 6). One of the farms reported reduced abundance of Pterygoplichthys spp. in one of their ponds in which water depth increased to 6-7 $\mathrm{ft}$ after renovation. Direct and indirect financial losses by the stakeholders of EKW due to Pterygoplichthys spp. were calculated between ₹0.0625 lakh and 0.193 lakhs ha-1 $\mathrm{yr}^{-1}$ (Table 7).

Table 4. Attitude and perception of respondents towards Pterygoplichthys spp. $\left(\mathrm{n}=\mathrm{N}_{2}=120\right)$

\begin{tabular}{|c|c|c|c|}
\hline $\begin{array}{l}\text { Response } \\
\text { category }\end{array}$ & $\begin{array}{l}\text { No. and } \% \text { of } \\
\text { respondents }\end{array}$ & Community perception towards Pterygoplichthys spp. & $\begin{array}{l}\text { Overall Perception } \\
(\%)\end{array}$ \\
\hline Positive & $0(0 \%)$ & ---- & $0 \%$ \\
\hline & & $\begin{array}{l}\text { - Overgrasing the wetland } \\
\text { - Cause of pond productivity depletion } \\
\text { - Cause of reduction in fish production and thus results in economic loss } \\
\text { - Cause of small indigenous fish depredation } \\
\text { - Cause of damage to fishing net }\end{array}$ & $\begin{array}{l}17 \% \\
43 \% \\
87 \% \\
73 \% \\
67 \%\end{array}$ \\
\hline Negative & $117(97.5 \%)$ & $\begin{array}{l}\text { - Block access of other fishes in and around their dominion } \\
\text { - Changing pond bottom/dyke structure by excavating deep holes } \\
\text { - Small-scale bank/bund erosion } \\
\text { - Cause of injury to other fishes due to strong dorsal and pectoral spines of these } \\
\text { catfish } \\
\text { - Impact on overall income from fisheries is not significant } \\
\text { - Being voracious herbivore may be good for algal control in wastewater pond }\end{array}$ & $\begin{array}{l}13 \% \\
67 \% \\
13 \% \\
17 \% \\
2.5 \% \\
1 \%\end{array}$ \\
\hline Neutral & $03(2.5 \%)$ & $\begin{array}{l}\text { - Good demand in many places as aquarium fish } \\
\text { - Though cause changes in pond bottom structure; ploughing of pond bottom by } \\
\text { these fishes may be good for soil-bound nutrient release }\end{array}$ & $\begin{array}{l}2 \% \\
1 \%\end{array}$ \\
\hline
\end{tabular}


Table 5. Mitigation measures reported by the respondents to reduce Pterygoplichthys spp. in their farms $\left(\mathrm{n}=\mathrm{N}_{2}=120\right)$

\begin{tabular}{lll}
\hline Control/preventive measures & No. of response & $\%$ of respondents \\
\hline $\begin{array}{l}\text { Culling after repeated netting } \\
\text { Removal of whole Eichhornia layer of the pond to net-out these fishes completely, } \\
\text { as they concentrate below this vegetation. }\end{array}$ & 120 & $100 \%$ \\
$\begin{array}{l}\text { Pay the fishermen @ ₹2.00 per kg of Pterygoplichthys spp. caught to motivate them } \\
\text { to catch as many as possible for killing. }\end{array}$ & 11 & $2.5 \%$ \\
\hline
\end{tabular}

Table 6. Farmers' opinion on effective solution to control Pterygoplichthys spp. $\left(\mathrm{n}=\mathrm{N}_{2}=120\right)$

\begin{tabular}{ll}
\hline Variable & $\%$ of respondents \\
\hline Don't Know & $24 \%$ \\
$\begin{array}{l}\text { Culling after repeated netting/drying } \\
\text { Multi-layer screening in the inlet of sewage water to pond (while water is taken by utilising }\end{array}$ & $33 \%$ \\
gravity gradient). & $31 \%$ \\
Pumping of sewage water from sewage distributaries to pond with proper screening & $12 \%$ \\
\hline
\end{tabular}

Table 7. Calculated direct and indirect financial losses due to Pterygoplichthys spp. in EKW (per ha per year)

\begin{tabular}{|c|c|c|c|}
\hline \multirow{2}{*}{ Variable } & \multicolumn{3}{|c|}{ Calculated loss (₹)** } \\
\hline & Min. & Max. & Average \\
\hline Loss of harvest of cultured fish (IMCs): min. 57 kg and max. $200 \mathrm{~kg} @ 80 \mathrm{~kg}^{-1}$ & 4,560 & 16,000 & 6,897 \\
\hline Scaling down harvest of small indigenous fishes: min. $0.23 \mathrm{~kg}$ and max. $1.2 \mathrm{~kg} @ 100 \mathrm{~kg}^{-1}$ & 23 & 120 & 59 \\
\hline Loss in terms of fish food organism depletion*** & 1,239 & 2,602 & 1,763 \\
\hline Loss in terms of incentive to fishermen to catch these fishes as much as possible & 21 & 95 & 48 \\
\hline Loss in terms of damage to fishing gears & 208 & 208 & 208 \\
\hline Loss in terms of pond bottom/dyke deterioration & 200 & 300 & 237 \\
\hline Total loss per ha per yr & 6,251 & 19,325 & 9,212 \\
\hline
\end{tabular}

${ }^{* *}$ Loss calculation is indirectly based on the response of the farmers

${ }^{* * *}$ Calculated as cost of sewage water used/need to be use in excess to maintain productivity

\section{Discussion}

Establishment of Pterygoplicthys population in the water bodies of EKW may be related to the congenial environment in the form of Eichhornia shed and ample food in the form of detritus provided by this ecosystem (Mendoza et al., 2009; Rueda-Jasso et al., 2013; Hussan, 2016). Eichhornia mats provide shelter as well as breeding ground for Pterygoplicthys and thus greater abundance of these fishes was noticed along the periphery of the ponds. Catch of more number of non-gravid smaller sized adult fishes from open water area during breeding season also indicate their preference for shelter/hide-outs, particularly by gravid fishes, during breeding season. It may also be an indicator of intra-species competition for shelter for successful breeding as well as for protecting offsprings from threats. To obtain actual abundance status of Pterygoplicthys spp. in EKW, alternate fishing techniques such as repeated netting after removal of Eichhornia layer in the ponds or catching after complete drying of the ponds may need to be used. Occurrence of the four common species of Pterygoplicthys from lentic as well as lotic water bodies in different parts of India have been reported (Muralidharan et al., 2015; Bijukumar et al., 2015; Reenamole and Ambili, 2016; Rama Rao and Sunchu, 2017).

Majority (84\%) of the specimens recorded during the present study have intermediary belly pattern, suggesting dominance of probable hybrids between $P$. disjunctivus and $P$. pardalis or other species of this genus, in EKW. Wu et al. (2011) also hypothesised possible natural and/ or artificial hybridisation of Pterygoplichthys spp. with complicated intra-specific variations and suggested that hybrid between $P$. pardalis and $P$. disjunctivus might have increased the fitness of their offspring and thus facilitated superiority of this hybrid population into invaded environments. In India, intermediary forms of Pterygoplichthys spp. with unknown identity were also reported by Bijukumar et al. (2015) from the drainages of Thiruvananthapuram City, Kerala.

The size range of the armoured catfish found in our study was comparable to that of P. disjunctivus in Adolfo 
Lopez Mateos El Infiernillo Reservoir, MichoacanGuerrero, Mexico (Rueda-Jasso et al., 2013) and of Pterygoplichthys spp. in drainage of Kerala (Bijukumar et al., 2015). The maximum size specimen recorded $(1200 \mathrm{~g})$ from EKW is also comparable with the armoured catfish collected from Churumuco, Mexico which was $520 \mathrm{~mm}$ in total length (TL) and $1280 \mathrm{~g}$ in weight (RuedaJasso et al., 2013). Possible existence of still larger individuals of Pterygoplichthys spp. in EKW cannot be discounted as Gibbs et al. (2013) concluded that $P$. disjunctivus can live up to 5.25 years and grow up to $51.5 \mathrm{~cm}$ standard length (SL) with a rapid growth rate of approximately $10 \mathrm{~cm}$ per year. Negative allometric growth of Pterygoplichthys spp. with 'b' value of 2.79 found in the present study comply with the findings of Liang et al. (2005), Samat et al. (2008) and Rueda-Jasso et al. (2013), which indicates that the fish tend to become thinner and less round with increasing length. Fluctuation in ' $b$ ' values of Pterygoplichthys spp. between locations of EKW could be attributable to the fish's response to different ecological conditions, as reported by many other researchers (Sangun et al., 2007; Samat et al., 2008). Strong correlation between total length and weight found in the present study $\left(\mathrm{r}^{2}=0.941\right)$ was similar to that of $P$. disjunctivus reported from Mexico (Rueda-Jasso et al., 2013). The number of eggs per brood of Pterygoplichthys recorded in the EKW $(\mathrm{AF}=2705 \pm 826$ eggs per fish $)$ is comparable with the total fecundity of $P$. disjunctivus recorded in Mexico (2447 \pm 252 eggs per fish) (Rueda-Jasso et al., 2013) or fecundity of Hypostomus sp. and Pterygoplichthys sp. reported from Texas (Cook-Hildreth et al., 2016); but far lower than that reported for $P$. disjunctivus caught from Marikina River, Philippines (AF $=7705 \pm 216$ eggs per fish) (Jumawan et al., 2016) or P. pardalis from Langat River of peninsular Malaysia with $>4000$ eggs per fish (Samat et al., 2016).

Twenty nine out of thirty farms surveyed reported occurrence of Pterygoplichthys spp. in their farms. Traits like ability to withstand water pollution (Welcomme and Vidthayanom, 2003), tolerance to poor oxygen content in water due to their ability for accessory respiration with diverticula of the gastrointestinal tract (Armbruster, 1998), capacity to downregulate metabolism during periods of scarcity of food (MacCormack et al., 2003), less vulnerability to predation due to spiny fins and hardened external morphology (Zworykin and Budaev, 2013) may have facilitated establishment of selfmaintaining populations of Pterygoplichthys spp. in EKW. Eighty percent of the farms reported rapid increase of Pterygoplichthys spp. population in their farms, which may also be linked to its feeding and reproductive behaviour. They feed primarily on periphyton and detritus (Ozedilek, 2007), which are usually abundant in EKW.
These fishes have capacity to alter the ecosystem and biodiversity of the invasion sites (Hoover et al., 2004; Zworykin and Budaev, 2013), which stakeholders of EKW also ascertained. They reported Pterygoplichthys as one of the reason for the declining species diversity and depleted catches of small indigenous fishes in their water bodies. This grasp of the EKW stakeholders corroborates with the findings of Mendoza et al. (2009) who reported displacement of native fishes from Lake Okeechobee, Florida by $P$. multiradiatus. Destruction of spawning and shelter ground and alteration of food availability for natives by grazing on benthic algae and detritus are cited as the reason of native fish decline in Pterygoplichthys invaded water bodies (Hossain et al., 2008; Hoover et al., 2004; Mendoza et al., 2009; Knight, 2010). Pond productivity depletion reported by most of the stakeholders during the study, may be due to sequestration of nitrogen and phosphorus of the system by Pterygoplichthys, through their body armour (Capps et al., 2009; Capps and Flecker, 2013). Loss in total fish production due to Pterygoplichthys recorded in EKW, concur the findings of Sumanasinghe and Amarasinghe (2013), who reported 21\% replacement of commercial fishes in Polgolla Reservoir of Sri Lanka by accidently introduced $P$. pardalis.

Changes in pond bottom/dyke structure by excavating deep holes perceived by more than $67 \%$ of the interviewees of EKW is in accordance with the findings of Nico et al. (2009) who reported that, male of adult loricariid catfishes excavate and maintain burrows (holes) in the banks of water bodies for use as spawning and nesting sites. Nico et al. (2009) recorded all or most burrows of Pterygoplichthys spp. concentrated within one meter depth of the river bank, suggesting low depth preference by these fishes. Damage of fishing net by these fishes as reported by the fishers of EKW, not only contribute to economic loss, but also makes fishing nets less effective for catching target species (Sumanasinghe and Amarasinghe, 2013). Economic losses to fishermen by $P$. multiradiatus by damaging equipment such as cast and gillnets and displacing native fishes in India (Krishnakumar et al., 2009); by $P$. disjunctives and $P$. pardalis by damaging cages and nets and reducing availability of more desirable fish in Laguna de Bay, Philippines (Chavez et al., 2006) were also reported.

Eradication of these fishes is regarded difficult, potentially time consuming and not feasible economically (Hill and Sowards, 2015) and hence efforts should be focused to contain the current established populations and preventing future introductions (Lawson et al., 2015; Hill et al., 2017). So, to prevent new introduction, EKW farmers are sieving sewage water through multilayer 
screen before taking it to their ponds and also practicing intensive netting to limit upsurge of existing population. Sumanasinghe and Amarasinghe (2013) also concluded 'intensive fishing' as one of the effective and feasible means of controlling population growth of armoured catfishes. Hill and Sowards (2015) reported complete eradication of $P$. disjunctivus from lower Rainbow River of Florida by hand and fish spear with an effort of two years. Chaichana and Jongphadungkiet (2012) suggested physical effort as the most effective way to control the spread of these species to other natural water bodies. They also opined for biological control using native predatory fishes in already invaded water bodies. In an experiment at Thailand they found that the bagrid catfish, Hemibagrus wyckioides and the marbled sleeper Oxyeleotris marmorata, readily prey on juvenile $P$. pardalis $(0.6-10 \mathrm{~cm}$ total length) and concluded that these fishes can be used for early life-stage removal of $P$. pardalis $(<10 \mathrm{~cm}$ size $)$. In India we also need to look for such options with our indigenous fishes.

The non-indigenous armoured catfishes of the genus Pterygoplichthys has caused havoc throughout the water bodies of aquaculture systems of EKW. Perception of stakeholders also points towards mounting pressure of these fishes on the already dwindling indigenous fishes and economy of EKW. The magnitude of impacts of these fishes is yet to be assessed in India, though these catfishes have already invaded in water bodies of wide parts of the country starting from North-east to Kerala with a serious mark of their reckless aggression. In this juncture, we suggest systematic studies on armoured catfishes to: i) record the number of armoured catfish species existing in the country, ii) gather knowledge on biology of these fishes critically investigating their habits including niche, mechanism of invasion, food habits, reproduction and ecological adaptability and iii) develop techniques for their utility as ingredient for feed preparation or other means through value addition, as they may contribute a substantial amount of protein. Eventually, a concerted effort is urgently required to check armoured catfishes to save our indigenous fish diversity and ecosystems. Changing their sex through genetic manipulation may be tried as one of the best efforts to check their population else their severity may bring ecological catastrophe particularly in aquaculture of EKW in near future when we have no way to restore such precious wetlands.

\section{Acknowledgements}

Authors are thankful to the fishermen of EKW for their support and co-operation; Director, ICAR-CIFA for providing facilities and encouragement; and Mr. Gourab Choudhury, SRF, RRC-Rahara, ICAR-CIFA for the help rendered in morphometric data collection.

\section{References}

Armando, T. W. K., Ramon, R. C. and Enrique, A. A. 2007. Amazon sailfin catfish Pterygoplichthys pardalis (Castelnau, 1885) (Loricariidae), another exotic species established in south-eastern Mexico. Southwest. Nat., 52(1): 141-144. DOI: 10.1894/0038-4909(2007)52[141: ASCPPC]2.0.CO;2.

Armbruster, J. W. 1998. Modifications of the digestive tract for holding air in loricariid and scoloplacid catfishes. Copeia, 3: 663-675. https://doi.org/10.2307/1447796.

Armbruster, J. W. 2001. Loricariids. http://www.auburn.edu/ academic/science_math/res_area/loricariid/fish_key/ lorhome/main.html (Accessed 4 March 2017).

Armbruster, J. W. 2003. The species of the Hypostomus cochliodon group (Siluriformes: Loricariidae). Zootaxa, 249: 1-60. DOI: 10.11646/zootaxa.249.1.1.

Armbruster, J. W. and Page, L. M. 2006. Redescription of Pterygoplichthys punctatus and description of a new species. Neotrop. Ichthyol., 4: 401-409. doi.org/10.1590/ S1679-62252006000400003.

Berra, T. M. 2001. Freshwater fish distribution. Academic Press, London, $607 \mathrm{pp}$.

Bijukumar, A., Smrithy, R., Sureshkumar, U. and George, S. 2015. Invasion of South American suckermouth armoured catfish Pterygoplichthys spp. (Loricariidae) in Kerala, India a case study. J. Threat. Taxa, 7(3) : 6987-6995. doi. org/10.11609/JoTT.o4133.6987-95.

Brown-Peterson, N. J., Wyanski, D. M., Saborido-Rey, F., Macewicz, B. J. and Lowerre-Barbieri, S. K. 2011. A standardised terminology for describing reproductive development in fishes. Mar. Coast. Fish., 3: 52-70. http:// dx.doi.org/10.1080/19425120.2011.555724.

Bunkley-Williams, L., Williams, Jr., E. H., Lilystrom, C. G., Corujo-Flores, I., Zerbi, A. J. and Aliaume, C. 1994. The South American sailfin armored catfish, Liposarcus multiradiatus (Hancock), a new exotic established in Puerto Rican freshwaters. Caribb. J. Sci., 30(1-2) : 90-94.

Capps, K. A., Flecker, A. S. and Rodiles-Hernandez, R. 2009. COS 45-8: Exotic fishes alter nutrient dynamics in tropical streams. 93 ${ }^{\text {rd }}$ ESA Annual Meeting Summary, http://eco. confex.com/eco/2009/techprogram/P16502.HTM.

Capps, K. A. and Flecker, A. S. 2013. Invasive aquarium fish transform ecosystem nutrient dynamics. Proc. Royal Soc. London B., 280: 1520. http://dx.doi.org/10.1098/ rspb.2013.1520.

Chaichana, R., Pouangcharean, S. and Yoonphand, R. 2011. Habitat, abundance and diet of invasive suckermouth armored catfish (Loricariidae: Pterygoplichthys) in the Nong Yai Canal, East Thailand. Trop. Zool., 24: 49-62.

Chaichana, R. and Jongphadungkiet, S. 2012. Assessment of the invasive catfish Pterygoplichthys pardalis (Castelnau, 1855) in Thailand: ecological impacts and biological 
control Alternatives. Trop. Zool., 25(4): 173-182. doi.org/1 $0.1080 / 03946975.2012 .738494$

Chavez, M. J., De La Paz, R. M., Manohar, S. K., Pagulayan, R. C. and Vi, C. 2006. New Philippine record of South American sailfin catfishes (Pisces: Loricariidae). Zootaxa, 1109 : 57-68. DOI: 10.11646/zootaxa.1109.1.6.

Clavero, M. and Garcia-Berthou, E. 2005. Invasive species are a leading cause of animal extinctions. Trends Ecol. Evol., 20: 110 .

Clavero, M. and Garcia-Berthou, E. 2006. Homogenisation dynamics and introduction routes of invasive freshwater fish in the Iberian Peninsula. Ecol. Appl., 16: 2313-2324. doi.org/10.1890/1051-0761(2006)016[2313:HDAIRO ]2.0.CO;2

Cook-Hildreth, S. L., Bonner, T. H. and Huffman, D. G. 2016. Female reproductive biology of an exotic suckermouth armored catfish (Loricariidae) in the San Marcos River, Hays Co., Texas with observations on environmental triggers. Bioinvasions Rec., 5: 173-183. http://dx.doi. org/10.3391/bir.2016.5.3.09.

Covain, R. and Fisch-Muller, S. 2007. The genera of the Neotropical armored catfish subfamily Loricariinae (Siluriformes: Loricariidae): A practical key and synopsis. Zootaxa, 1462 : 1-40. DOI: 10.11646/zootaxa.1462.1.1.

Edwards, P. 2008. An increasingly secure future for wastewater fed aquaculture in Kolkata, India. Aquac. Asia, 13(4): 3-9.

EKW 2010. East Kolkata Wetlands Newsletter, vol. I, New Delhi, India, 24 pp.

Eldredge, L. G. 2000. Non-indigenous freshwater fishes, amphibians and crustaceans of the Pacific and Hawaiian Islands. In: Sherley, G. (Ed.), Invasive species in the Pacific: a technical review and draft regional strategy. South Pacific Regional Environment Programme, Apia, Samoa, p. 173-190.

Elton, C. S. 1958. The ecology of invasions by animals and plants. Methuen, London.

Ferraris, C. J. 2007. Checklist of catfishes, recent and fossil (Osteichthyes: Siluriformes) and catalogue of siluriform primary types. Zootaxa, 1418: 1-628.

Freitas, D., Gomes, J., Sales Luis, T., Madruga, L., Marques, C., Baptista, G., Rosalino, L. M., Antunes, P., Santos, R. and Santos-Reis, M. 2007. Otters and fish farms in the Sado Estuary: ecological and socio-economic basis of a conflict. Hydrobiologia, 587: 51-62. DOI: 10.1007/s10750-0070693-7.

Garcia-Berthou, E. 2007. The characteristics of invasive fishes: what has been learned so far? J. Fish Biol., 71 (Suppl. D): 33-55. doi:10.1111/j.1095-8649.2007.01668.x.

Gibbs, M. A., Kurth, B. N. and Bridges, C. D. 2013. Age and growth of the loricariid catfish Pterygoplichhtys disjunctivus in Volusia Blue Spring, Florida. Aquat. Invasions, 8(2): 207-218. http://dx.doi.org/10.3391/ai.20 13.8.2.08.

Golani, D. and Snovsky, G. 2013. Occurrence of suckermouth armored catfish (Siluriformes, Loricariidae, Pterygoplichthys) in inland waters of Israel. Bioinvasions Rec., 2(3): 253-256. https://doi.org/10.3391/bir.2013.2.3.13.

Graham, K., Beckerman, A. P. and Thirgood, S. 2005. Humanpredator-prey conflicts: Ecological correlates, prey losses and patterns of management. Biol. Conserv., 122: 159-171. DOI: 10.1016/j.biocon.2004.06.006.

Herder, F., Schliewen, U. K., Geiger, M. F., Hadiaty, R. K., Gray, S. M., McKinnon, J. S., Walter, R. P. and Pfaender, J. 2012. Alien invasion in Wallace's Dreamponds: records of the hybridogenic "flowerhorn" cichlid in Lake Matano, with an annotated checklist of fish species introduced to the Malili Lakes system in Sulawesi. Aquat. Invasions, 7(4): 521-535. doi.org/10.5072/RIN/G8GMXK.

Hill, J. E. and Sowards, J. 2015. Successful eradication of the non-native loricariid catfish Pterygoplichthys disjunctivus from the Rainbow River, Florida. Manag. Biol. Invasions, 6(3): 311-317. http://dx.doi.org/10.3391/mbi.2015.6.3.11.

Hill, J. E., Tuckett, Q. M., Hardin, S., Lawson, Jr. L. L., Lawson, K. M., Ritch, J. L. and Partridge, L. 2017. Risk screen of freshwater tropical ornamental fishes for the conterminous United States. Trans. Am. Fish. Soc., 146(5): 927-938.

Hoover, J. J., Killgore, K. J. and Cofrancesco, A. F. 2004 Suckermouth catfishes: threats to aquatic ecosystems of the United States? Aquatic Nuisance Species Research Program. Engineers Research and Development Center, Vicksburg, MS. ANSRP Bulletin, 4(1): 1-13.

Hossain, M. Y., Rahman, M. M., Ahmed, Z. F., Ohtomi, J. and Islam, A. B. M. S. 2008. First record of the South American sailfin catfish Pterygoplichthys multiradiatus in Bangladesh. J. Appl. Ichthyol., 24: 718-720. doi. org/10.5072/RIN/G8GMXK.

Hubilla, M., Kis, F. and Primavera, J. 2007. Janitor Fish Pterygoplichthys disjunctivus in the Agusan Marsh: a threat to freshwater biodiversity. J. Environ. Sci. Manag., 10(1): 10-23.

Hussan, A. 2016. Threats to fish diversity of East Kolkata Wetlands and conservation needs. Aquac. Times, 2(6): 10-15.

Hussan, A., Choudhury, T. G., Das, A. and Gita, S. 2016. Suckermouth sailfin catfishes: A future threat to aquatic ecosystems of India. Aquac. Times, 2(6): 20-22. https:// www.researchgate.net/publication/322255227

Hussan, A., Mandal, R. N., Hoque, F., Das, A., Chakrabarti, P. P. and Adhikari, S. 2018. Dominance of intergrades of invasive suckermouth armoured catfishes Pterygoplichthys spp. (Siluriformes: Loricariidae) in coastal wetlands of West Bengal, India. J. Indian Soc. Coastal Agric. Res., 36(1): 84-92. 
ICAR 2009. Annual report 2008-09. Indian Council of Agricultural Research, Department of Agricultural Research and Education, Ministry of Agriculture, Government of India, New Delhi.

Jumawan, J. C., Vallejo, B. M., Herrera, A. A., Buerano, C. C. and Fontanilla, K. C. 2011. DNA barcodes of the suckermouth sailfin catfish Pterygoplichthys (Siluriformes: Loricariidae) in the Marikina River system, Philippines: Molecular perspective of an invasive alien fish species. Philipp. Sci. Lett., 4(2): 102-113.

Jumawan, J. C., Herrera, A. A., Jumawan, J. H. and Vallejo Jr. B. 2016. Size structure and reproductive phenology of the suckermouth sailfin catfish Pterygoplichthys disjunctivus (Weber, 1991) from Marikina River, Philippines. ARPN J. Agric. Biol. Sci., 11(1): 18-23.

Kloskowski, J. 2005. Otter Lutra lutra damage at farmed fisheries in south-eastern Poland, I: an interview survey. Wildlife Biol., 11: 201-206. DOI: 10.2981/0909-6396 (2005)11[201:OLLDAF]2.0.CO;2

Knight, J. D. M. 2010. Invasive ornamental fish: a potential threat to aquatic biodiversity in peninsular India. J. Threat. Taxa, 2(2): 700-704. https://doi.org/10.11609/ JoTT.o2179.700-4.

Kolar, C. S. and Lodge, D. M. 2001. Progress in invasion biology: predicting invaders. Trends Ecol. Evol., 16: 199204. DOI: 10.1016/S0169-5347(01)02101-2.

Kolar, C. S. and Lodge, D. M. 2002. Ecological predictions and risk assessment for alien fishes in North America. Science, 5596: 1233-1235. DOI: 10.1126/science. 1075753.

Krishnakumar, K., Raghavan, R., Prasad, G., Bijukumar, A., Sekharan, M. and Periera, B. 2009. When pets become pests-exotic aquarium fishes and biological invasions in Kerala, India. Curr. Sci., 97: 474-476.

Lakra, W. S., Singh, A. K. and Ayyappan, S. 2008. Fish introduction in India: Status, potential and challenges. Narendra Publishers, New Delhi.

Lawson, L. L., Hill, J. E., Hardin, S., Vilizzi, L. and Copp, G. H. 2015. Evaluation of the fish invasiveness screening kit (FISK v2) for peninsular Florida. Manag. Biol. Invasions, 6(4): 413-422.

Le Cren, E. D. 1951. The length-weight relationships and seasonal cycle in gonad weight and condition in the perch (Perca fluviatilis). J. Anim. Ecol., 20: 201-219. DOI: 10.1126/science. 1075753

Levin, B. A., Phuong, P. H. and Pavlov, D. S. 2008. Discovery of the Amazon sailfin catfish Pterygoplichthys pardalis (Castelnau, 1855) (Teleostei: Loricariidae) in Vietnam. J. Appl. Ichthyol., 24: 715-717. DOI: 10.1111/j.14390426.2008.01185.x.

Liang, S. H., Wu, H. P. and Shieh, B. S. 2005. Size structure, reproductive phenology and sex ratio of an exotic armored catfish (Liposarcus multiradiatus) in the Kaoping River of southern Taiwan. Zool. Stud., 44(2): 252-259.
MacCormack, T. J., McKinley, R. S., Roubach, R., Almeida-Val, V. M. F., Val, A. L. and Driedzic, W. R. 2003. Changes in ventilation, metabolism and behaviour, but not bradycardia, contribute to hypoxia survival in two species of Amazonian armoured catfish. Can. J. Zool., 81: 272-280. DOI: 10.1139/ z03-003.

Mendoza, R. E., Cudmore, B., Orr, R., Balderas, S. C., Courtenay, W. R., Osorio, P. K., Mandrak, N., Torres, P. A., Damian, M. A., Gallardo, C. E., Sanguines, A. G., Greene, G., Lee, D., Orbe-Mendoza, A., Martinez, C. R. and Arana, O. S. 2009. Trinational risk assessment guidelines for aquatic alien invasive species. Commission for Environmental Cooperation 393, rue St-Jacques Ouest, Bureau 200, Montreal (Quebec), Canada. ISBN 978-2-923358-48-1.

Mogalekar, H. S., Jawahar, P., Srinivasan, A., Karal Marx, K., Sujathkumar, N. V., Canciyal, J. and Sudhan, C. 2017. Discovery of the Amazon sailfin catfish Pterygoplichthys pardalis (Castelnau, 1855) (Teleostei: Loricariidae) from Manimuthar dam, Tamiraparani River system, India. J. Entom. Zool. Stud., 5(4): 1229-1231.

Muralidharan, M., Manikandan, K. and Gobi, M. 2015. Extended distribution of the invasive sucker catfish Pterygoplichthys pardalis (Pisces: Loricariidae) to Cauvery River system of Peninsular India. Int. J. Aquat. Biol., 3(1): 14-18.

Murua, H. G., Kraus, F., Saborido-Rey, F., Wittzhames, P. R., Thorsen, A. and Junquera, S. 2003. Procedures to estimate fecundity of marine fish species in relation to their reproductive strategy. J. North Atlantic Fish. Sci., 33: $33-54$.

Nakabo, T. 2002. Fishes of Japan with pictorial keys to the species. Tokai University Press, Tokyo, 2428 pp.

Nico, L. G. and Martin, T. R. 2001. The South American suckermouth armored catfish, Pterygoplichthys anisitsi (Pisces: Loricariidae), in Texas, with comments on foreign fish introductions in the American Southwest. Southwest Nat., 46 (1): 98-104. doi:10.2307/3672381.

Nico, L. G., Jelks, H. L. and Tuten, T. 2009. Non-native suckermouth armored catfishes in Florida: description of nest burrows and burrow colonies with assessment of shoreline conditions. Aquat. Nuisance Species Res. Bull., 9: 1-30.

Nico, L. G., Butt, P. L., Johnson, G. R., Jelks, H. L., Kail, M. and Walsh, S. J. 2012. Discovery of the South American suckermouth armoured catfish (Loricariidae, Pterygoplichthys spp.) in the Santa Fe River drainage, Suwannee River basin, USA. Bioinvasion Rec., 1:179-200. http://dx.doi.org/10.3391/bir.2012.1.3.04.

Orfinger, A. B. and Goodding, D. D. 2018. The global invasion of the suckermouth armored catfish genus Pterygoplichthys (Siluriformes: Loricariidae): Annotated list of species, distributional summary and assessment of impacts. Zool. Stud., 57(7): 235-246. doi:10.6620/ZS.2018.57-07.

Ozdilek, S. Y. 2007. Possible threat for Middle East inland water: an exotic and invasive species, Pterygoplichthys 
disjunctivus (Weber, 1991) in Asi River, Turkey (Pisces: Loricariidae). Egyptian J. Fish. Aquat. Sci., 24(3-4): 303-306.

Padilla, D. K. and Williams, S. L. 2004. Beyond ballast water: aquarium and ornamental traders as source of invasive species in aquatic ecosystems. Frontiers Ecol. Environ., 2: 131-138. doi.org/10.1890/1540-9295(2004)002[0131:BB WAAO]2.0.CO;2.

Page, L. M. and Robins, R. H. 2006. Identification of sailfin catfishes (Teleosti: Loricariidae) in south-eastern Asia. Raffles Bull. Zool., 54: 455-457.

Parkhurst, J. A., Brooks, R. P. and Arnold, D. E. 1987. A survey of wildlife depredation and control techniques at fish rearing facilities. Wildl. Soc. Bull., 15: 386-394.

Peh, K. S. H. 2010. Invasive species in South-east Asia: the knowledge so far. Biodivers. Conserv., 19: 1083-1099. DOI : 10.1007/s10531-009-9755-7.

Piazzini, S., Lori, E., Favilli, L., Cianfanelli, S., Vanni, S. and Manganelli, G. 2010. Invasion note: a tropical fish community in thermal waters of southern Tuscany. Biol. Invasions, 12: 2959-2965. https://doi.org/10.1007/s10530010-9695-x.

Raghavan, R. N., Dahanukar, M. F., Tlusty, A. L., Rhyne, K., Kumar, K., Molur, S. and Rosser, A. M. 2013. Uncovering an obscure trade: Threatened freshwater fishes and the aquarium pet markets. Biol. Conserv., 164: 158-169. https://doi.org/10.1016/j.biocon.2013.04.019.

Rahel, F. J. 2002. Homogenisation of freshwater faunas. Annual Rev. Ecol. Syst., 33: 291-315. doi.org/10.1146/annurev. ecolsys.33.010802.150429.

Rama Rao, K. and Sunchu, V. 2017. A report on Pterygoplichthys pardalis Amazon sailfin suckermouth catfishes in freshwater tanks at Telangana State, India. Int. J. Fish. Aquat. Stud., 5(2): 249-254.

Ramsar 2002. Information sheet on Ramsar wetlands (RIS).. https://rsis.ramsar.org/RISapp/files/RISrep/IN1208RIS.pdf (Accessed 17 April 2017).

Ramsar 2017. The list of wetlands of international importance. https://www.ramsar.org/sites/default/files/documents/ library/sitelist.pdf (Accessed 17 April 2017).

Reenamole, G. R. and Ambili, T. 2016. Occurrence of suckermouth armoured sailfin catfishes in Vellayani freshwater lake, Kerala, south-west coast of India. Int. J. Sci. Res., 5(3): 1142-1145.

Rixon, C. A. M., Duggan, I. C., Bergeron, N. M. N., Ricciardi, A. and Macisaac, H. J. 2005. Invasion risks posed by the aquarium trade and live fish markets on the Laurentian Great Lakes. Biodivers. Conserv., 14: 1365-1381. http:// dx.doi.org/10.1007/s10531- 004-9663-9.

Rueda-Jasso, R. A., Campos-Mendoza, A., Arreguin-Sanchez, F., Diaz-Pardo, E. and Martinez-Palacios, C. A. 2013. The biological and reproductive parameters of the invasive armored catfish Pterygoplichthys disjunctivus from Adolfo Lopez Mateos El Infiernillo Reservoir, MichoacanGuerrero, Mexico. Rev. Mex. Biodivers., 84: 318-326. http://dx.doi.org/10.7550/rmb26091.

SAC 2010. National wetland atlas: Assam, 2010. SAC/RESA/ AFEG/NWIA/ATLAS/18/2010, Space Applications Centre (ISRO), Ahmedabad, India, 174 pp.

Samat, A., Shukor, M. N., Mazlan, A. G., Arshad, A. and Fatimah, M. Y. 2008. Length-weight relationship and condition factor of Pterygoplichthys pardalis (Pisces: Loricariidae) in Malaysia Peninsula. Res. J. Fish. Hydrobiol., 3: 48-53.

Samat, A., Yusoff, F. M., Arshad, A., Ghaffar, M. A., Nor, S. M., Magalhaes, A. L. B. and Das, S. K. 2016. Reproductive biology of the introduced sailfin catfish Pterygoplichthys pardalis (Pisces: Loricariidae) in peninsular Malaysia. Indian J. Fish., 63(1): 35-41. doi:10.21077/ijf.2016.63. 1.44937-05

Sangun, L., Akamcal, E. and Akar, M. 2007. Weight-length relationships for 39 fish species from the North-eastern Mediterranean coast of Turkey. Turk. J. Fish. Aquat. Sci., 7: $37-40$

Sato, M., Kawaguchi, Y., Nakajima, J., Mukai, T., Shamatani, Y. and Onikura, N. 2010. A review of the research on introduced freshwater fishes: new perspectives, the need for research and management implications. Landscape Ecol. Eng., 6: 99-108. DOI: 10.1007/s11355-009-0086-3

Simon, K. D., Bakar, Y., Samat, A., Zaidi, C. C., Aziz, A. and Mazlan, A. G. 2009. Population growth, trophic level and reproductive biology of two congeneric archer fishes (Toxotes chatareus, Hamilton 1822 and Toxotes jaculatrix, Pallas 1767) inhabiting Malaysian coastal waters. J. Zhejiang Univ. Sci. B., 10(12): 902-911. doi: 10.1631/ jzus.B0920173

Singh, A. K. and Lakra, W. S. 2011. Risk and benefit assessment of alien fish species of the aquaculture and aquarium trade into India. Rev. Aquac., 3: 3-18. https://doi.org/10.1111/ j.1753-5131.2010.01039.x.

Singh, A. K., Kumar, D., Srivastava, S. C. and Ansari, A. 2013. Invasion and impacts of alien fish species in the Ganga River, India. Aquat. Ecosyst. Health Manage., 16(4): 408-414. https://doi.org/10.1080/14634988.2013.857974.

Singh, A. K. 2014. Emerging alien species in Indian aquaculture: prospects and threats. J. Aquat. Biol. Fish., 2: 32-41.

Sinha, R. K., Sarkar, U. K. and Lakra, W. S. 2010. First record of the southern sailfin catfish, Pterigoplichthys anisitsi Eigenmann \& Kennedy, 1903 (Teleostei: Loricariidae), in India. J. Appl. Ichthyol., 26: 606-608. https://doi. org/10.1111/j.1439-0426.2010.01474.x.

Skaren, U. 1990. Fish farming and otters in Finland. IUCN Otter Specialist Group Bull., 5: 28-34.

Solomon, F. N. and Ramnarine, I. W. 2007. Reproductive biology of white mullet, Mugil curema (Valenciennes) 
in the Southern Caribbean. Fish. Res., 88: 133-138. DOI: 10.1016/j.fishres.2007.06.024.

Sumanasinghe, H. P. W. and Amarasinghe, U. S. 2013. Population dynamics of accidentally introduced Amazon sailfin catfish, Pterygoplichthys pardalis (Siluriformes, Loricariidae) in Pologolla Reservoir, Sri Lanka. Sri Lanka J. Aquat. Sci., 18: 37-45. https://doi.org/10.4038/sljas. v18i0.7040.

Trindade, A. 1991. Fish farming and otters in Portugal. IUCN Otter Specialist Group Bull., 6.

UN 1992. Alien species that threaten ecosystems, habitats or species [Article $8(\mathrm{~h})]$. Convention on Biological Diversity, http://www.cbd.int. (Accessed 4 March 2017)

Wakida-Kusunoki,A.T.,Ruiz-Carus, R. andAmador-del-Angel,E. 2007. Amazon sailfin catfish, Pterygoplichthys pardalis (Castelnau, 1855) (Loricariidae), another exotic species established in Southeastern Mexico. Southwest. Nat., 52: 141-144. doi:10.1894/0038-4909(2007)52[141:ASCPPC] 2.0.CO;2.

Weber, C. 1991. Nouveaux taxa dans Pterygoplichthys sensulato (Pisces, Siluriformes, Loricariidae). Revue Suisse de Zool., 98: 637-643.
Weber, C. 1992. Revision du genre Pterygoplichthys sensulato (Pisces, Siluriformes, Loricariidae). Revue Francaised' Aquariologie Herpetologie, 19: 1-36.

Weber, C. 2003. Loricariidae - Hypostominae (Armored catfishes). In: Reis, R. E., Kullander, S. O., Ferraris, Jr., C. J. (Eds.), Checklist of the freshwater fishes of south and central America, Porto Alegre: EDIPUCRS, Brazil, p. 351-372.

Welcomme, R. L. and Vidthayanom, C. 2003. The impacts of introductions and stocking of exotic species in the Mekong Basin and policies for their control. MRC Technical Paper No. 9, Mekong River Commission, Phnom Penh, Vietnam.

West, B. C. and Parkhurst, J. A. 2002. Interactions between deer damage, deer density and stakeholder attitudes in Virginia. Wildl. Soc. Bull., 30: 139-147. DOI: 10.2307/3784647.

Wu, L. W., Liu, C. C. and Lin, S. M. 2011. Identification of exotic sailfin catfish species (Pterygoplichthys, Loricariidae) in Taiwan based on morphology and mtDNA sequences. Zool. Stud., 50: 235-246.

Zworykin, D. D. and Budaev, S. V. 2013. Non-indigenous armoured catfish in Vietnam: invasion and systematics. Ichthyol. Res., 60(4): 327-333. http://dx.doi.org/10.1007/ s10228-013-0356-9.

Date of Receipt $\quad$ : 19.01 .2019

Date of Acceptance : $\quad$ 26.04.2019 